\title{
The Immunoglobulin G Subclass Composition of Immune Complexes in Cystic Fibrosis \\ Implications for the Pathogenesis of the Pseudomonas Lung Lesion
}

Douglas B. Hornick and Robert B. Fick, Jr.

Pulmonary Disease Division, Department of Internal Medicine, College of Medicine, University of Iowa, Iowa City, Iowa 52242

\begin{abstract}
It has been shown that pulmonary macrophage (PM) phagocytosis of Pseudomonas aeruginosa (PA) is inhibited in the presence of serum from cystic fibrosis (CF) patients colonized by Pseudomonas, and that these sera contain high concentrations of IgG2 antibodies. The goal of these studies was to investigate the role that IgG2-containing immune complexes (IC) play in this inhibition of both PM and neutrophil phagocytosis. We found that serum IgG2 concentrations were elevated significantly in CF patients with chronic PA colonization and that in selected sera from CF patients with chronic PA colonization $(C F+I C, n=10)$, the mean IC level was significantly elevated (2.90 $\pm 0.22 \mathrm{mg} / \mathrm{dl}$ [SEM]). IgG2 comprised $74.5 \%$ of IgG precipitated in IC from CF + IC sera. An invitro phagocytic assay of $\left[{ }^{14} \mathrm{C} P \mathrm{PA}\right.$ uptake using $\mathrm{CF}+\mathrm{IC}$ whole-sera opsonins confirmed that endocytosis by normal PM and neutrophils was significantly depressed. Removal of IC from CF + IC sera resulted in significantly decreased serum IgG 2 concentrations without a significant change in the other subclass concentrations, and enhanced $\left[{ }^{14} \mathrm{C}\right] \mathrm{PA}$ uptake by PM $(26.6 \%$ uptake increased to $47.3 \%)$ and neutrophils $(16.9 \%$ increased to $52.6 \%$ ). Return of the soluble IgG2 IC to the original CF sera supernatants and the positive control sera resulted in return of the inhibitory capacity of the CF + IC sera. We conclude that immune sera from patients with chronic Pseudomonas infections characterized by elevated IgG2 subclass level functions poorly as an opsonin. In these individuals, IgG2 contributes significantly to circulating IC and removal of IC, matched by a simultaneous fall in IgG2, improves bacterial uptake by neutrophil and mononuclear phagocytes. IgG2 antibodies exert antiphagocytic effects by both direct inhibition and the formation of IC. (J. Clin. Invest. 1990. 86:1285-1292.) Key words: bronchoalveolar lavage - phagocytosis - pulmonary macrophage
\end{abstract}

\section{Introduction}

Immune complexes have been identified in the sera of cystic fibrosis $(\mathrm{CF})^{1}$ patients with a reported incidence that varies from $23 \%$ to $86 \%(1-4)$. The occurrence of circulating immune

This article was submitted in competition for the 1987 Cecile Lehman Mayer Research Award, American College of Chest Physicians.

Address reprint requests to Dr. Hornick, Pulmonary Disease Division, Department of Medicine, University of Iowa Hospitals and Clinics, Iowa City, IA 52242.

Received for publication 31 January 1989 and in revised form 9 May 1990.

J. Clin. Invest.

(c) The American Society for Clinical Investigation, Inc. $0021-9738 / 90 / 10 / 1285 / 08 \quad \$ 2.00$

Volume 86, October 1990, 1285-1292 complexes (IC) is thought to be related to respiratory exacerbations $(1,2)$, deteriorating pulmonary function $(2,3)$, age of CF patients (1), the presence of chronic airways infection caused by Pseudomonas aeruginosa (PA; reference 4) and associated with significant increases in IgG antibody to pseudomonas (2). The observation of increased IC concentrations in sera, lung tissues $(5,6)$, and sputa (4) of CF patients with chronic pseudomonas infection and the poor prognosis of these patients (7) may point to local IC formation in the lungs. We and others have suggested that defective CF serum opsonophagocytosis may be related to defective $\mathrm{Fc} \gamma$ function of $\mathrm{CF}$ IgG antibodies (8), or that an IgG2 subclass response, a subclass with a low affinity for pulmonary macrophages (PM) Fc-receptors, may contribute to defective cellular clearance of PA from the human airway (9). PA may persist in the airways, exerting a stimulus for production of high titers of IgG2 antibodies, resulting in appropriate conditions for IC formation.

We propose that IgG2 antibodies in high concentrations selectively inhibit clearance of PA by PM. If this is observed, it follows that the predominant immunoglobulin component of CF IC would be IgG2. Furthermore, IC may competitively inhibit effective phagocytosis of opsonized PA cleared through PM Fc-receptor binding. The present studies measured the IgG subclass contribution to CF IC and employed an in vitro phagocytic assay of normal human PM and neutrophils to study the phagocytosis of a ${ }^{14} \mathrm{C}$-tagged clinical isolate of mucoid PA. We found an inhibition of the phagocytic process by IgG2-containing IC.

\section{Methods}

Subjects and serum specimens. Sera obtained from $18 \mathrm{CF}$ young adults with chronic PA colonization of at least 1 yr duration were screened for the presence of immune complexes. 10 with the highest IC levels were selected for study in greater detail (CF + IC). There were four females and six males with a mean age of $17.9 \pm 1.4 \mathrm{yr}$ (range 10-24 yr). Sera were also obtained (generously provided by Dr. Donald Livsey, Specialty Laboratory, Inc., Los Angeles, CA) from 11 non-CF patients with significant elevations of $\mathrm{IgG} 2(\mathrm{IgG} 2=1,088 \pm 119 \mathrm{mg} / \mathrm{dl},>2 \mathrm{SD}$ above normal mean). Many of these individuals suffered from allergic respiratory symptoms or chronic airways infections. All sera samples were obtained in the outpatient setting during routine follow-up visits. None of these patients were receiving antibiotics at the time serum was obtained. Control sera were obtained from healthy laboratory personnel ("NS", $n=4$ ). PA hyperimmune serum (PAIS) was provided by Parke-Davis, Morris Plains, NJ and consisted of pooled serum from normal volunteers vaccinated with PA heptavalent lipopolysaccharide (LPS) vaccine (Pseudogen vaccine, Parke-Davis). All sera were stored at $-70^{\circ} \mathrm{C}$ if not used within $48 \mathrm{~h}$; samples for more immediate use were maintained at $4^{\circ} \mathrm{C}$.

1. Abbreviations used in this paper: $\mathrm{CF}$, cystic fibrosis; IC, immune complex(es); PA, Pseudomonas aeruginosa; PAIS, Pseudomonas aeruginosa hyperimmune serum; PM, pulmonary macrophages. 
Isolation, measurement, and dissociation of IC. IC levels in CF sera were measured by a Clq solid-phase competitive binding assay (10) performed as a courtesy by the laboratory of David P. Huston, MD (Baylor College of Medicine, Houston, TX). All samples were run in triplicate and the results expressed in milligrams per deciliter.

Complexes were precipitated from serum by $2.7 \%$ polyethylene glycol 6000 (PEG) after the methods of Berdischewsky et al. (1). At $4^{\circ} \mathrm{C}$ $2 \mathrm{vol}$ of serum were mixed with $1 \mathrm{vol}$ of $8 \%$ PEG in PBS (wt/vol, pH $=7.2)$ for $1 \mathrm{hr}$, then precipitated at $1,000 \mathrm{~g}$ at $4^{\circ} \mathrm{C}$ for $1 \mathrm{hr}$. The pellet was washed in $2.7 \%$ PEG and resuspended to one-half the original serum volume in a dissociating solution of $0.1 \mathrm{M}$ glycine $/ \mathrm{HCl}, \mathrm{pH} 3.0$.

The serum supernatants were preserved for use later in an hemagglutination assay (HA) and a phagocytic assay. The solution containing partially purified and resuspended IC was used in the hemagglutination assay, in an enzyme-linked immunosorbent assay (ELISA) to quantify total IgG precipitated, and in the phagocytic assay in "add back" experiments in which IC were returned to the original serum supernatants. Our own data (unpublished) and the work of others (11) suggest that there is increasing precipitation of noncomplexed IgG and other proteins with higher concentrations of PEG, but the contamination is insignificant below 6\% PEG concentrations. It was determined, however, that $0.1 \mathrm{M}$ glycine/ $\mathrm{HCl}, \mathrm{pH} 3.0$ or $\mathrm{pH} 7.0$, and PEG both had inhibitory effects on endocytosis of opsonized bacteria. Therefore, the reconstituted IC serum was dialyzed against borate $(0.16 \mathrm{M} \mathrm{NaCl}$, $0.22 \mathrm{M} \mathrm{H}_{3} \mathrm{BO}_{3}, \mathrm{pH} 8.0$ ) to remove $0.1 \mathrm{M}$ glycine and PEG, and to normalize the $\mathrm{pH}$, followed by concentration through positive pressure (UM-10 membrane, Amicon Corp., Danvers, MA) to closely approximate the original serum volume. Borate was found to have no independent effect in the phagocytic assay.

$\operatorname{Ig} G$ and $\operatorname{Ig} G$ subclass assays. Total IgG was determined by ELISA after the method of Rennard et al. (12). Flat-bottom 96-well microtiter plates (Immulon, Dynatech Laboratories, Alexandria, VA) were coated with commercially obtained human IgG (Sigma Chemical Co. St. Louis, MO), at $0.2 \mu \mathrm{g}$ per well dissolved in $0.035 \mathrm{M}$ sodium bicarbonate, $\mathrm{pH} 9.6$ (Voller's buffer). IgG-containing samples were diluted serially $1: 3$ with $20 \mathrm{mM}$ sodium phosphate, $0.15 \mathrm{M} \mathrm{NaCl}$, plus $0.05 \%$ Tween 20 (PBS/Tween) in round-bottom microtiter plates (Dynatech Laboratories) and incubated for 120 min with dilute rabbit antihuman IgG antibody (ICN Biochemicals, Lisle, IL) at room temperature. The contents of each well were transferred to the flat-bottom wells, then incubated at room temperature for $30 \mathrm{~min}$. After washing with PBS/Tween, horseradish peroxidase (HRP)-coupled goat antirabbit IgG antibody (ICN Biochemicals), previously adsorbed 1:1 ( $\mathrm{vol} / \mathrm{vol})$ with normal human serum was added to each well and incubated for $90 \mathrm{~min}$. The secondary antibody studied by immunodiffusion against normal human serum and the normal human IgG used to coat flat-bottomed plates showed no precipitation arc. After washing with PBS/Tween, the enzyme substrate $o$-phenylenediamine (Sigma Chemical Co.) in methanol $10 \mathrm{mg} / \mathrm{ml}$ (diluted 1:100 in $0.03 \% \mathrm{H}_{2} \mathrm{O}_{2}$ made fresh before use) was added to each well and incubated for $\sim 30$ min. The enzyme reaction was then quenched with $8 \mathrm{M} \mathrm{H}_{2} \mathrm{SO}_{4}$. Plates were read in a microplate spectrophotometer at $490 \mathrm{~nm}$ (Bio-Tek Instruments, Inc., Winooski, VT). The useful range of the assay was from 0.1 to $50 \mu \mathrm{g} / \mathrm{ml}$. Samples were diluted into the approximate range, measured in duplicate, and compared to a serially diluted 10 $\mu \mathrm{g} / \mathrm{ml} \mathrm{IgG} \mathrm{standard.} \mathrm{Results} \mathrm{are} \mathrm{expressed} \mathrm{as} \mathrm{milligrams} \mathrm{per} \mathrm{deciliter.}$

Subclasses 1-4 were quantitated on all sera by commercially available radial immunodiffusion plates using normal serum standards provided (ICN Biochemicals). Results are expressed as milligrams per deciliter and as the percentage of the arithmetic total of the four measured IgG subclass levels in a given sample.

Passive microhemagglutination assay. This standard technique was adapted from Neter et al. (13) to measure antibody reactivity to PA. In brief, serum was pretreated with $0.1 \mathrm{M} 2$-mercaptoethanol at $37^{\circ} \mathrm{C}$ for $1 \mathrm{~h}$ to remove the contribution of IgM agglutinins. Blood type $\mathrm{O}$ erythrocytes were obtained from a normal volunteer and washed in
$0.9 \% \mathrm{NaCl}$. Then a $10 \%$ erythrocyte solution in PBS was mixed 1:1 (vol/vol) with $100 \mu \mathrm{g} / \mathrm{ml}$ PA LPS antigens, Fisher immunotypes 1-7 (Pseudogen vaccine) and incubated for 30 minutes at $37^{\circ} \mathrm{C}$. The washed erythrocytes were then ready for use and were added $(50 \mu \mathrm{l})$ to duplicate, serial $1: 2$ dilutions of serum with $7.5 \%$ bovine serum albumin in 96 well-round bottom microtiter plates (Dynatech Laboratories). Agglutination of antigen-coated erythrocytes was determined after 4-6 h of incubation at room temperature.

Isolation of macrophages and neutrophils. This technique was similar to that used in previous reports from this lab (14). Briefly, the day before each planned phagocytic assay informed consent was obtained from a patient undergoing diagnostic bronchoscopy and bronchoalveolar lavage was performed in uninvolved lobes of lung. All patients were smokers and otherwise in good health at the time of the procedure. Smokers were selected because prior studies have shown that the phagocytic competence of PM is not affected by smoking (15) and a larger number of PM can be obtained from these individuals. Subsegmental lavage of the right middle lobe and/or the lingula was performed by instilling $20-\mathrm{ml}$ aliquots of sterile $0.9 \% \mathrm{NaCl}$ and immediately aspirating with low wall suction $\left(-80 \mathrm{~cm} \mathrm{H}_{2} \mathrm{O}\right)$ for a total volume of $100 \mathrm{ml}$ at each site. Lavage fluid return was routinely $60-70 \%$ of instilled volume.

PM were isolated as per our routine lab protocol $(8,14)$. The cells were resuspended in serum free RPMI (University of Iowa Tissue Culture and Hybridoma Facility). The lung lavage cell pellet was used to prepare a cytospin microscope slide and the cell differential was enumerated on Wright's stained cells. Cell viability was determined by trypan blue dye exclusion. Cell counts were performed by hemocytometer. The final concentration was adjusted to $1 \times 10^{6}$ viable cells/ $\mathrm{ml}$ in serum-free RPMI supplemented with glutamine $(1 \%, \mathrm{wt} / \mathrm{vol})$ and gentamycin $(100 \mu \mathrm{g} / \mathrm{ml}) .1-\mathrm{ml}$ aliquots were added to each well of flat-bottom tetrad tissue culture plates (Nunc, Copenhagen, Denmark), and PM were then allowed to adhere, being maintained $16 \mathrm{~h}$ in humidified, $5 \% \mathrm{CO}_{2}$ atmosphere, at $37^{\circ} \mathrm{C}$. Just before use in the phagocytic assay cells were reexamined microscopically and washed in sterile HBSS without $\mathrm{Ca}^{++}$and $\mathrm{Mg}^{++}$, to remove nonadherent cells and cellular debris. Neutrophils were isolated from normal human whole blood using the standard hypaque-ficoll gradient centrifugation technique (16).

Radioactive bacteria. The ${ }^{14} \mathrm{C}$-labeled PA were prepared using a previously reported technique (8). In brief, an aliquot of $P$. aeruginosa, a mucoid sputum isolate from a CF patient (M309), was used. This strain, characteristic of CF isolates, was nontypable using the Difco International System and nonmucoid revertants were known to agglutinate in type 1 sera of the Fisher immunotyping system. Multiple aliquots had been previously frozen at $-70^{\circ} \mathrm{C}$ in $20 \%$ (vol/vol) sterile glycerol-enriched tryptic soy broth. PA were thawed and inoculated into $20 \mathrm{ml}$ of tryptic soy broth, along with $0.025 \mu \mathrm{Ci} \mathrm{L}-\left[{ }^{14} \mathrm{C}\right]$ amino acid mixture (New England Nuclear, Boston, MA), and incubated on a shaker platform for $14-16 \mathrm{~h}$ at $37^{\circ} \mathrm{C}, 5 \% \mathrm{CO}_{2}$, humidified atmosphere. Bacteria were then washed up to four times in $0.9 \% \mathrm{NaCl}$ until there was minimal detectable radioactivity in the supernatant. Using a Petroff-Hauser counting chamber (Fisher Scientific Co., Itasca, IL) and dark-field microscope the concentration of bacteria was adjusted to 1 $\times 10^{8}$ bacteria $/ \mathrm{ml}$.

Phagocytic assays. The ${ }^{14} \mathrm{C}$-labeled PA $\left(\left[{ }^{14} \mathrm{C}\right] \mathrm{PA}\right)$ uptake by $\mathrm{PM}$ in the presence of $10 \%$ serum $(\mathrm{vol} / \mathrm{vol})$ was determined using the in vitro phagocytic assay technique previously reported (8). In summary, serum was added in duplicate to PM monolayers such that final concentration was $10 \%$ of the total volume. The serum and the $2.7 \%$ PEG supernatants from CF + IC, NS, PAIS serving as a positive control, and $0.9 \% \mathrm{NaCl}$, a negative control, were tested in this phagocytic assay. Representative serum samples in initial experiments were divided and one half underwent heating to $56^{\circ} \mathrm{C}$ for $30 \mathrm{~min}$ immediately before use in the assay to assess the contribution of complement. In addition, IC previously isolated from the CF patients were added to $(a)$ the original 
serum supernatant in an attempt to reconstitute the inhibitory factor in the sera specimens; and $(b)$ the positive immune sera control, PAIS, in order to demonstrate the inhibitory effect of the immune complexes on the phagocytic process.

HBSS supplemented with $\mathrm{Ca}^{++}$and $\mathrm{Mg}^{++}$was used when necessary to bring the final assay volume to $1.0 \mathrm{ml}$. Each assay well received ${ }^{14} \mathrm{C}$-labeled PA such that the ratio of bacteria to phagocytic cell was 10:1. The monolayers were incubated at $37^{\circ} \mathrm{C}$ for $1 \mathrm{~h}$ on a rotating platform. Each well was then washed with cold $\left(4^{\circ} \mathrm{C}\right) \mathrm{HBSS}$ without $\mathrm{Ca}^{++}$and $\mathrm{Mg}^{++}$. After three washes, distilled $\mathrm{H}_{2} \mathrm{O}$ was added to each well and the PM were manually lifted by gently scraping with a rubber policeman. The wells were checked by phase-contrast microscopy to assure complete removal. The whole-cell suspension was transferred to $20-\mathrm{ml}$ glass vials and mixed with liquid scintillation fluid, $10 \mathrm{ml}$ (Beckman Instruments, Inc., Arlington Heights, IL), and vortexed vigorously. The ${ }^{14} \mathrm{C}$ activity per well was determined in a scintillation counter (Beckman Instruments, Inc., Palo Alto, CA).

Neutrophils were also used as the phagocytic cell adapting a standard method (16). Cells were freshly obtained the day of the assay from whole blood of normal human volunteers, counted by hemocytometer, and checked for viability by trypan blue dye exclusion. The assay was always performed in duplicate in a total volume of $1.0 \mathrm{ml}$ (HBSS, supplemented with $\mathrm{Ca}^{++}$and $\mathrm{Mg}^{++}$) containing $1 \times 10^{6}$ cells, a final serum concentration of $10 \%(\mathrm{vol} / \mathrm{vol})$, and $10: 1\left[{ }^{14} \mathrm{C}\right] \mathrm{PA}$ to neutrophil ratio. The phagocytic cells were added just before incubation for $1 \mathrm{~h}$ in humidified $5 \% \mathrm{CO}_{2}, 37^{\circ} \mathrm{C}$, on a tumbling platform. After centrifugation at $150 \mathrm{~g}$, at $4^{\circ} \mathrm{C}$, supernatants were removed, and chilled $2 \mathrm{mM}$ $\mathrm{NaF}$ was added to assure termination of phagocytosis. Phagocytic cells were washed and then digested using $0.5 \mathrm{~N} \mathrm{NaOH}$ at $37^{\circ} \mathrm{C}$ for $18 \mathrm{~h}$, and cell-associated counts were determined in a liquid scintillation counter after neutralizing $\mathrm{NaOH}$ with $3 \%$ acetic acid.

To quantify the PM and neutrophil uptake of ${ }^{14} \mathrm{C}$-labeled PA, the mean specific activity of the initial inoculum of ${ }^{14} \mathrm{C}$-labeled PA was determined. The ratio of measured ${ }^{14} \mathrm{C}$ counts in the phagocytic cell suspension divided by the specific activity of the inoculum $\times 100$ is reported as the percent $\left[{ }^{14} \mathrm{C}\right] \mathrm{PA}$ uptake. By these methods an insignificant amount of cell-associated $\left[{ }^{14} \mathrm{C}\right] \mathrm{PA}$ are attached to the surface and not internalized as previously proven (8).

Statistical analysis. Arithmetic means and standard error of the means were calculated from results of the Clq assay, IgG-ELISA, subclass determinations, hemagglutination assay, and the phagocytic data. Results were analyzed using Student's $t$ test for compared data; $P$ values reported are for two-tailed tests.

\section{Results}

Concentrations of IC, serum IgG, and antibody titers to PA antigen. The mean IC concentration in the $\mathrm{CF}+\mathrm{IC}$ sera was $2.90 \pm 0.22 \mathrm{mg} / \mathrm{dl}$ (Table I). In this assay system four normal sera revealed a mean level of $0.62 \pm 0.12 \mathrm{mg} / \mathrm{dl}(\mathrm{CF}+\mathrm{IC}$ vs. normal sera, $P<0.01$ ). The total $\mathrm{IgG}$ concentration deter-

Table I. Immune Complex Levels

\begin{tabular}{|c|c|}
\hline Serum source & Immune complexes \\
\hline & $m g / d l$ \\
\hline $\begin{array}{l}\text { Normal serum } \\
\quad(n=4)\end{array}$ & $0.62 \pm 0.12$ \\
\hline $\begin{array}{c}C F+I C \text { serum } \\
(n=10)\end{array}$ & $2.90 \pm 0.22^{*}$ \\
\hline
\end{tabular}

Abbreviations: $\mathrm{CF}+\mathrm{IC}$, selected $\mathrm{CF}$ patients with elevated IC levels. ${ }^{*} \mathrm{CF}+\mathrm{IC}$ vs. normal, $P<0.01$. mined by ELISA (Table II, column 2) demonstrated, as expected, that the CF patients had elevated serum IgG levels. Mean total IgG was $2,782 \pm 482 \mathrm{mg} / \mathrm{dl}$ compared to normal sera and the PAIS which were $1,587 \pm 380 \mathrm{mg} / \mathrm{dl}$ and $1,004 \pm 7$ $\mathrm{mg} / \mathrm{dl}$, respectively ( $P<0.01$ for both comparisons).

The IgG titers to PA surface antigenic lipopolysaccharide (PA LPS) are also listed in Table II (column 7). The highest titers to PA LPS were in the PAIS (> 1:4,096). The sera from CF patients with chronic PA colonization also had high titers yielding a mean value of $1: 1,587$. Interestingly, a significant antibody titer to PA LPS (1:82) was measured in the precipitated and dissociated IC from the CF + IC sera.

CF sera with elevated IC $(n=3)$ were treated with $2.7 \%$ PEG and the precipitate was analyzed by immunoelectrophoresis. Antiserum to human serum proteins used to study these precipitates produced an immunoprecipitation arc identical to heat aggregated IgG. Occasionally, albumin was also identified in these precipitates.

IgG subclass composition of $C F$ sera and IC. The serum IgG subclass levels for the $C F$ patients displayed an increase in IgG2 concentration (Table II, column 4) at $1,178 \mathrm{mg} / \mathrm{dl}$, compared to $435 \pm 95 \mathrm{mg} / \mathrm{dl}$ normal sera $\mathrm{IgG} 2$ concentration $(P$ $<0.01$ ). IgG2 comprised $74.5 \%$ of the measured subclasses within the IC precipitate from CF + IC sera. When the subclass profile of IgG precipitated from NS was attempted, only IgG1 was detectable in quantities sufficient to measure; other subclasses were below the threshold of detection. IgG2 was not preferentially precipitated by PEG from either NS or PAIS. In addition other immunoglobulins (IgA, IgM) and albumin were not detected in significant quantities within the $2.7 \%$ PEG precipitates. Therefore, the observation that CF + IC IC contained primarily IgG2 immunoglobulins appears not to be artifactual.

It has been stated that the PEG method for detection of IC in serum is nonspecific. It has been suggested that even at low concentrations, PEG causes precipitation of $\mathrm{IgG}$ which may be "nonspecifically aggregated" and is not part of the IC measured by other techniques such as C1q or Raji cell assays. To address this problem, the IgG ELISA was used to determine the fraction of the total serum IgG precipitated by $2.7 \%$ PEG. Normal serum yielded $0.54 \pm 0.01 \%$ of the total serum IgG as a precipitate, while the $C F+$ IC sera yielded $0.89 \pm 0.13 \%$ of the total serum $\mathrm{IgG}$ as a precipitate (absolute amount: $0.07 \pm 0.01$, and $0.21 \pm 0.03 \mathrm{mg}$, respectively; NS vs. $\mathrm{CF}+\mathrm{IC}, P<0.01$ ). The larger fraction of IgG precipitated from CF + IC sera is attributable to IC measured by $\mathrm{Clq}$ assay.

IgG2 concentrations in CF + IC sera were reduced to the upper limit of the normal range, $766 \pm 123 \mathrm{mg} / \mathrm{dl}$, after removal of IC (Table II, column 4 , final line). This was a significant decrease when compared to $1,178 \pm 192 \mathrm{mg} / \mathrm{dl}$ IgG2 concentration in the intact CF + IC sera $(P<0.01)$. This resulted in a shift in the relative IgG2 content from $42.0 \%$ to $31.5 \%$ and the overall relative proportions of the four subclasses in $\mathrm{CF}$ sera also returned to normal values. The changes in relative proportions of other subclasses after precipitation of IC were not significant.

Pulmonary macrophage clearance of $P$. aeruginosa. Results of the in vitro phagocytic assay using PM (Table III) revealed that the percent uptake of $\left[{ }^{14} \mathrm{C}\right] \mathrm{PA}$ was greatest when PAIS was used to opsonize the bacteria. This is as predicted based on the 
Table II. Immunochemical Profiles of Experimental Sera

\begin{tabular}{|c|c|c|c|c|c|c|}
\hline $\begin{array}{l}\text { Column } 1 \\
\text { Source }\end{array}$ & $\stackrel{2}{\operatorname{IgG}^{*}}$ & $\stackrel{3}{\lg G 1^{*}}$ & $\stackrel{4}{\operatorname{IgG} 2}$ & $\stackrel{5}{\operatorname{IgG} 3}$ & $\stackrel{6}{\operatorname{lgG} 4}$ & $\begin{array}{c}7 \\
\text { Mean reciprocal } \\
\text { HA titer }\end{array}$ \\
\hline $\begin{array}{l}\text { Normal serum } \\
\quad(n=4)\end{array}$ & $1,587 \pm 380$ & $\begin{array}{c}1,087 \pm 165 \\
(66.7)\end{array}$ & $\begin{array}{c}435 \pm 95 \\
(26.1)\end{array}$ & $\begin{array}{c}58 \pm 16 \\
(3.8)\end{array}$ & $\begin{array}{c}58 \pm 1.4 \\
(3.4)\end{array}$ & $<8$ \\
\hline $\begin{array}{l}\text { PAIS } \\
\quad(n=2)\end{array}$ & $1,004 \pm 7$ & $\begin{array}{c}978 \pm 44 \\
(66.2)\end{array}$ & $\begin{array}{r}293 \pm 6 \\
(20.0)\end{array}$ & $\begin{array}{c}162 \pm 25 \\
(10.9)\end{array}$ & $\begin{array}{r}43 \pm 3 \\
(2.9)\end{array}$ & $>4,096$ \\
\hline $\begin{array}{c}\text { CF + IC serum } \\
(n=10)\end{array}$ & $2,782 \pm 482$ & $\begin{array}{c}1,286 \pm 98 \\
(49.6)\end{array}$ & $\begin{array}{c}1,178 \pm 192^{\prime \prime} \\
(42.0)\end{array}$ & $\begin{array}{c}128 \pm 11 \\
(4.9)\end{array}$ & $\begin{array}{c}89 \pm 22 \\
(3.5)\end{array}$ & $1,587 \pm 418$ \\
\hline $\begin{array}{c}\text { IC }(\mathrm{CF}+\mathrm{IC})^{\S} \\
\text { Precipitate } \\
(n=10)\end{array}$ & $0.21 \pm .03$ & $\begin{array}{l}8.2 \pm 2.1 \\
(22.5)\end{array}$ & $\begin{array}{c}32.0 \pm 7.9 \\
(74.5)\end{array}$ & $\begin{array}{c}0.8 \pm 0.1 \\
(2.5)\end{array}$ & $\begin{array}{c}0.2 \pm 0.1 \\
(0.7)\end{array}$ & 82 \\
\hline $\begin{array}{c}C F+I C(-I C) \\
\quad \text { Supernatant } \\
(n=10)\end{array}$ & $2,427 \pm 730$ & $\begin{array}{c}1,435 \pm 157 \\
(61.4)\end{array}$ & $\begin{array}{c}766 \pm 123 \\
(31.5)\end{array}$ & $\begin{array}{c}102 \pm 12 \\
(4.6)\end{array}$ & $\begin{array}{c}61 \pm 17 \\
(2.4)\end{array}$ & - \\
\hline
\end{tabular}

Abbreviations: CF + IC: CF patients with elevated IC levels. * Values determined by IgG-ELISA, results are mean mg/dl \pm SEM. ${ }^{\ddagger}$ IgG subclass values determined by radial immunodiffusion assay; results expressed as mean $\mathrm{mg} / \mathrm{dl} \pm \mathrm{SEM}$ (percent arithmetic sum of IgG subclasses).

${ }^{\S}$ All values in milligrams. "CF + IC vs. normal and CF + IC vs. CF + IC $(-$ IC $), P<0.01$.

IgG hemagglutinating titers to PA LPS (Table II, column 7). $\mathrm{NaCl}$, which lacks any opsonizing activity, served as the negative control. When normal serum was used to opsonize the bacteria the percent uptake of $\left[{ }^{14} \mathrm{C}\right] \mathrm{PA}$ was an intermediate value in comparison to the positive and negative controls (NS $=34.8 \%$ vs. PAIS $=82.6 \%$ and $\mathrm{NaCl}=7.7 \%, P<0.01$ for both comparisons). The CF + IC group sera, as previously reported for CF sera (8), was a less potent opsonin compared to normal sera $(\mathrm{CF}+\mathrm{IC}=26.6 \%$ vs. $\mathrm{NS}=34.8 \%, P<0.01)$, despite elevated titers to PA LPS $(1: 1,587)$. However, removal of IC from the CF + IC sera by $2.7 \%$ PEG precipitation significantly enhanced the mean $\left[{ }^{14} \mathrm{C}\right] \mathrm{PA}$ uptake by the PM from $26.6 \%$ to 47.3\% (Table III, final line, $P<0.01$ ). To lend further support to the hypothesis that the enhancement observed was the result of IC removal, data in Table IV $A$ showed that adding IC back to $\mathrm{CF}+\mathrm{IC}$ supernatants, resulted in reversal of the augmenta-

Table III. $\left[{ }^{14} \mathrm{C}\right] P$. aeruginosa Phagocytosis by Pulmonary Macrophages and Neutrophils in the Presence of Sera Opsonins*

\begin{tabular}{|c|c|c|c|c|}
\hline & \multicolumn{2}{|c|}{ Pulmonary macrophages } & \multicolumn{2}{|c|}{ Neutrophils } \\
\hline & Intact sera & Supernatant $t^{\ddagger}$ & Intact sera & Supernatant \\
\hline $\begin{array}{l}\mathrm{NaCl} \\
\quad(n=4)\end{array}$ & $7.7 \pm 1.4^{8}$ & $7.1 \pm 1.1$ & $10.2 \pm 1.9$ & $11.7 \pm 0.8$ \\
\hline $\begin{array}{l}\text { PAIS } \\
\quad(n=4)\end{array}$ & $82.6 \pm 9.8$ & $77.2 \pm 12.2$ & $85.4 \pm 2.7$ & $76.3 \pm 6.3$ \\
\hline $\begin{array}{l}\text { Normal serum } \\
\quad(n=4)\end{array}$ & $34.8 \pm 4.7^{\prime \prime}$ & $34.2 \pm 4.6$ & $23.6 \pm 1.0^{\prime \prime}$ & $18.5 \pm 2.1$ \\
\hline $\begin{array}{l}\mathrm{CF}+\mathrm{IC} \\
\quad(n=10)\end{array}$ & $26.6 \pm 1.5$ & $47.3 \pm 3.1^{\prime}$ & $16.9 \pm 1.1$ & $52.6 \pm 2.2$ \\
\hline
\end{tabular}

* Results unaffected by heat to $56^{\circ} \mathrm{C}$ for $30 \mathrm{~min}$.

\# After IC removal.

$\$$ Values expressed as mean percent $\left[{ }^{14} \mathrm{C}\right] \mathrm{PA}$ inoculum uptake $\pm \mathrm{SEM}$.

"Normal sera vs. CF + IC, $P<0.01$.

' CF + IC (supernatant) vs. CF + IC (intact sera), $P<0.01$. tion attained previously by removing IC from these sera (61.7\% without IC vs. $27.9 \%$ with IC, $P<0.01$ ). Potential contribution to this effect by dilution, residual PEG, $0.1 \mathrm{M}$ glycine $/ \mathrm{HCl}$, or borate buffer were all eliminated by manipulation of samples as outlined in the Methods section (Table IV $A$, "Supernatant Control"). The inhibitory effect of the IC was further demonstrated when the CF IC were added to PAIS and the combination was tested as a source of opsonic antibodies. Uptake was significantly reduced in PM from $67.4 \%$ to $38.8 \%$ (Table IV $A, P<0.01$ ). This effect was not seen when an identically prepared $2.7 \%$ PEG precipitate from PAIS serum was added to the PAIS supernatant. Uptake was $71.8 \%$ which

Table IV. Effect of Immune Complex Serum Supernatant Reconstitution on $\left[{ }^{14} \mathrm{C}\right] P A$ Uptake

\begin{tabular}{|c|c|c|c|c|}
\hline & Intact serum & Supernatant & $\begin{array}{l}\text { Supernatant-CF } \\
\text { IC added }\end{array}$ & $\begin{array}{l}\text { Supernatant } \\
\text { control }\end{array}$ \\
\hline \multicolumn{5}{|c|}{ A. Pulmonary macrophages } \\
\hline $\begin{array}{l}\text { CF + IC } \\
\quad(n=10)\end{array}$ & $32.5 \pm 3.9$ & $61.7 \pm 6.1^{11}$ & $27.9 \pm 3.7$ & $61.5 \pm 9.2^{\ddagger}$ \\
\hline $\begin{array}{l}\text { PAIS } \\
\qquad(n=3)\end{array}$ & $71.8 \pm 6.2$ & $67.4 \pm 10.3$ & $38.8 \pm 9.0$ & $71.8 \pm 8.3^{8}$ \\
\hline \multicolumn{5}{|c|}{ B. Neutrophils } \\
\hline $\begin{array}{l}\text { CF + IC } \\
\quad(n=10)\end{array}$ & $9.1 \pm 1.6$ & $55.4 \pm 7.7^{11}$ & $9.1 \pm 2.0$ & $44.7 \pm 9.2^{\ddagger}$ \\
\hline $\begin{array}{l}\text { PAIS } \\
\quad(n=3)\end{array}$ & $90.7 \pm 3.9$ & $85.1 \pm 2.4$ & $39.5 \pm 4.9$ & $75.8 \pm 5.8^{8}$ \\
\hline
\end{tabular}

* Values expressed as mean percent $\left[{ }^{14} \mathrm{C}\right] \mathrm{PA}$ inoculum uptake $\pm \mathrm{SEM}$.

${ }^{\ddagger}$ Buffer only, without CF IC.

$\$$ PEG precipitate recovered from PAIS instead of CF serum.

" For both CF + IC and PAIS: supernatant vs. supernatant-CF IC added, $P<0.01$. 
was no different from baseline uptake of $67.4 \%$ (Table IV $A$, "Supernatant Control"). PEG precipitation of other opsonizing sera (NS, PAIS, and $\mathrm{NaCl}$ ) also had no effect to augment bacterial uptake (Table III).

Neutrophil clearance of $P$. aeruginosa. Results of the in vitro neutrophil phagocytic assay (Table III, right side) for PAIS, $\mathrm{NaCl}$, and NS opsonins were consistent with their relative IgG hemagglutinating titers to PA LPS. Despite high titers to PA LPS, once again, the sera from the CF + IC group were less potent as opsonins compared to normal sera (CF + IC $=16.9 \%$ vs. $\mathrm{NS}=23.6 \%, P<0.01)$. PEG precipitation of IC from the CF + IC sera enhanced the mean $\left[{ }^{14} \mathrm{C}\right] \mathrm{PA}$ uptake by neutrophils from $16.9 \%$ to $52.6 \%$ (Table III, last line, $P$ $<0.01)$. The latter level was more consistent with the high serum titer to PA LPS in the CF + IC samples. Using the same approach as for the PM assay, this observed augmentation was reversed by adding the IC back to the original supernatants (Table IV $B$, column 3 ). Similarly, adding IC to the PAIS caused a significant reduction in uptake from $85.1 \%$ to $39.5 \%$ (Table IV $B, P<0.01$ ). This result was specific for CF IC. When identically prepared $2.7 \%$ PEG precipitate from PAIS serum was added to the PAIS supernatant, bacterial uptake was $75.8 \%$, which was not significantly different from baseline uptake of $85.1 \%$ (Table IV B, "Supernatant Control"). PEG precipitation of the other opsonin sources (i.e., $\mathrm{NaCl}$, PAIS, NS, CF-PA) resulted in no alterations in the baseline $\left[{ }^{14} \mathrm{C}\right] \mathrm{PA}$ endocytosis by neutrophils (Table III).

IgG2 effect on macrophage and neutrophil phagocytosis. In an attempt to provide corroborative data supporting the inhibitory effect of IgG2 on phagocytic cell uptake of $P$. aeruginosa sera specimens obtained from individuals with high IgG2 levels were employed with an in vitro assay of opsonophagocytosis. High IgG2 levels in the opsonic serum significantly inhibited uptake of ${ }^{14} \mathrm{C}$-tagged PA in both the neutrophil (IgG2 $=40.9 \pm 0.8 \%$ vs. $\mathrm{NS}=48.3 \pm 0.6 \%, P<0.01)$ and pulmonary macrophage (IgG2 $=6.8 \pm 0.1 \%$ vs. $23.9 \pm 2.4 \%, P<0.01$ ) systems (Fig. $1 a$ ). These results were unaffected by heating at $56^{\circ} \mathrm{C}$ for $30 \mathrm{~min}$. In separate experiments (Fig. $1 \mathrm{~b}$ ), removal of IgG2 from four of these sera samples by affinity chromatography resulted in a $51 \%$ increase in PM phagocytosis of the $\left[{ }^{14} \mathrm{C}\right] \mathrm{PA}(\mathrm{IgG} 2=38.3 \pm 0.3 \%$ vs. minus $\mathrm{IgG} 2=57.9 \pm 0.6, P$ $<0.01)$.

\section{Discussion}

There are poorly characterized inhibitory factors in CF serum, associated with chronic $P$. aeruginosa infections, which impair phagocytosis of PA. These factors effectively negate the impressive IgG titers to PA antigens found in CF sera which should be protective. In fact, IgG titers to PA antigens paradoxically correlate with clinically worsening pulmonary disease $(8,17-19)$. Recently, our laboratory has implicated IgG2 causally in this process by suggesting that it may act as a "blocking antibody" specific to pulmonary macrophages ( 9 , 20). The data presented here permit extension of this concept. These observations corroborate the earlier findings that IgG2 exerts an independent inhibitory effect in an in vitro phagocytic assay using PM.

The concept of blocking antibodies is controversial and has been suggested to explain the role that allergen specific IgG plays in preventing IgE antibody-mediated allergy to bee venom. In this situation, subclass IgG4 has been the potential mediator of the blocking effect by coating the offensive antigen, preventing it from binding to IgE (21). Importantly, G4 may be protective by virtue of the fact that, like IgG2, it has a low affinity for complement and Fc receptors on macrophages and lymphocytes (22). In this report we proposed an analogous mechanism involving IgG2 to account for the decreased clearance of pseudomonas in CF by PM. LPS, a prominent cell wall component common to gram-negative bacilli, is a key antigen for the humoral recognition and clearance of this pathogen (23-25). Our work has demonstrated that the IgG subclass response to PA LPS is restricted largely to IgG2 (9). IgG responses to many polysaccharide antigens are known to be restricted to subclass 2 (reviewed in reference 26). In patients with elevated serum IgG2 concentrations, such as CF patients (9), the predominant subclass coating PA may be IgG2. We reasoned that phagocytosis by human $\mathrm{PM}$, which have Fc receptors recognizing predominantly IgG3 and to a lesser degree IgG1 $(27,28)$, would be less effective in binding and, therefore, clearing organisms opsonized by serum with elevated IgG2 ( 9 , $20)$. This proposed mechanism for monomeric IgG2 may account for the inhibition of PM phagocytosis that reverses when the elevated IgG2 concentration is reduced as shown in Fig. 1. From other preliminary phagocytic experiments utilizing nor-

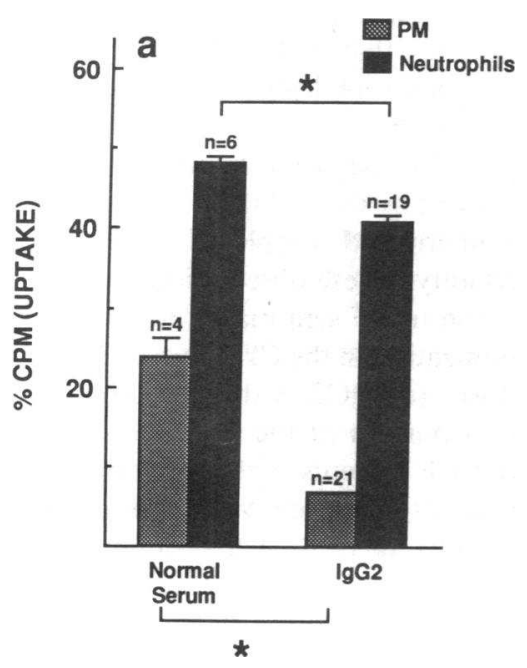

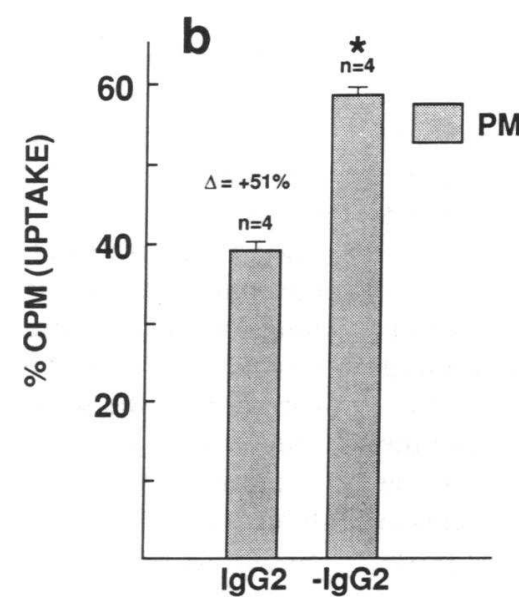

Figure 1. Endocytosis of $\left[{ }^{14} \mathrm{C}\right] \mathrm{PA}$ by $\mathrm{PM}$ and neutrophils in the presence of high titered IgG2 sera. (a) IgG2 sera samples when used in in vitro assays of opsonophagocytosis resulted in a significant decrease in bacterial uptake (ordinate). Uptake by PM (NS $23.9 \%$ ) fell to a mean $6.8 \%$ phagocytosis of radiotagged PA; neutrophils (NS mean 48.3\%) decreased to $40.9 \%(b)$ Independent experiments with selective removal of IgG2 resulted in a significant increase in the phagocytic function of PM. ${ }^{*} P<0.01$ for all comparisons indicated. 
mal pulmonary macrophages and sera from two CF patients without significant IC concentrations but significant IgG2 concentrations (29), we found that PM phagocytosis of $\left[{ }^{14} \mathrm{C}\right] \mathrm{PA}$ M309 was reduced compared to normal serum controls $(23.7 \pm 2.3 \%$ vs. $34.8 \pm 4.7 \%, P<0.01)$, and did not improve after $2.7 \%$ PEG precipitation. These findings are also consistent with the hypothesis that sera with high $\operatorname{IgG} 2$ concentrations alone serve as less potent opsonins in PM phagocytic assays.

In addition, neutrophils known to possess two classes of Fc-receptors referred to as FcRII and FcRlo, also have a similar restriction in subclass recognition. FcRII binds IgG2 significantly less than IgG1 and IgG3, which appear to have equal affinity (30); FcRlo bind IgG1 and IgG3 as well (31), whereas IgG2 binding has not been demonstrated. Therefore, this proposed mechanism for monomeric IgG2 probably accounts for the smaller, yet significant inhibition of neutrophil phagocytosis reported above.

Once established in CF patients, persistent airway PA perpetuates the inflammatory response and accelerates immunoglobulin synthesis, yet is poorly cleared as reasoned above, establishing ideal conditions for IC formation. The duration of PA colonization is correlated directly with $\operatorname{IgG}$ levels $(7,32)$. Relevant to this study is a recent longitudinal report of $\mathrm{CF}$ patients in which serum IgG antibody titers to PA LPS were followed over 15 years. The antibody titers appear at the onset of PA colonization and continue to rise to extremely high levels throughout the course of chronic colonization. The authors hypothesize that this setting predisposes $C F$ patients to IC mediated disease, especially in the end stages of disease, when the titers are the highest (19). The presence and concentration of IC in the sera of CF patients also correlates directly with the chronicity of PA colonization, as well as antibody titers to PA LPS $(1,33,34)$. IgG responses to PA LPS are largely restricted to subclass 2 (9) and in the present study we found that the HA titer to PA LPS was strikingly elevated in dissociated IC precipitated from CF + IC sera. The CF + IC sera also had a significant IgG2 subclass predominance in the precipitated IC.

It may be that IC may partially account for elevation in serum IgG2 reported previously $(9,32)$. IC removal from CF + IC sera is matched by a simultaneous, inseparable decrease in serum IgG2 levels to the upper limits of the normal range. This is observed without a concurrent significant change in the concentration of the other IgG subclasses. These results suggest that a portion of the previously reported increased concentrations of IgG2 (9) in CF sera are due to the presence of IgG2 in IC. More importantly, the results presented above are consistent with the hypothesis that chronic antigenic stimulus by PA LPS leads to high IgG2 antibody titers which may be measured as elevated serum IgG2 subclass, largely accounted for in IC.

The use of PEG to precipitate IC has been criticized because it nonspecifically precipitates small amounts of serum proteins other than IC $(35,36)$. This problem was minimized in our studies by $(a)$ using a low PEG concentration of $2.7 \%$ (up to $6 \%$ has been cited as selectively precipitating immune complexes) (11), (b) avoiding repetitive freezing and thawing of serum which tends to cause $\mathrm{IgG}$ and other serum proteins to aggregate and precipitate with PEG (37), and (c) when possible, maintaining serum at $4^{\circ} \mathrm{C}$ to be used within $48 \mathrm{~h}$.
The role of immune complexes in the pathogenesis of $\mathrm{CF}$ lung disease has been addressed by several authors with inconclusive results $(6,33,34,38)$. A possibility, not investigated here, is that the antigenic components of circulating IC may interfere with phagocytic cell endocytic function. It may be that the IC identified above and the monomeric IgG2 antibodies together provide explanations for the persistence of $P$. aeruginosa in CF airways. IC in CF serum may exert an inhibitory effect on both PM and neutrophil phagocytosis of PA by competing with opsonized bacteria for $\mathrm{Fc} \gamma$ receptor sites on the surface of these phagocytes. This may be a situation analogous to the often invoked but poorly documented IgG4 blocking antibody mechanism for allergen desensitization (discussed above). Therefore, bacteria-IgG2 complexes may contribute to the pathogenesis of CF lung disease through a mechanism other than complement activation. The results presented in Table 3 support this hypothesis. PM and neutrophil uptake of $\left[{ }^{14} \mathrm{C}\right] \mathrm{PA}$ when the opsonin was CF + IC sera, was depressed compared to NS. This appears paradoxical considering the high titers to PA LPS in CF + IC sera. When the IgG2 IC were removed, however, uptake of the $\left[{ }^{14} \mathrm{C}\right] \mathrm{PA}$ was markedly enhanced for both PM and neutrophils. The enhanced values in both cases were significantly greater than values obtained with normal serum opsonins and more consistent with predicted uptake given the elevation in PA LPS specific IgG titers. The data in Table IV clearly demonstrate the inimical effect of the IgG2 IC. Inhibition of $\left[{ }^{14} \mathrm{C}\right] \mathrm{PA}$ uptake was reinstated when the CF IgG2 IC were returned to the supernatants (second column from right). Furthermore, there was inhibition of both PM and neutrophil phagocytosis when the CF IgG2 IC were added to the positive control, PAIS, specifically implicating CF IgG2 IC in the PM and neutrophil phagocytosis-inhibitory activity of CF serum.

Phagocytic cells of acute inflammation, neutrophils, are recruited in large numbers to the CF lung in response to PA colonization as indicated by the large numbers of neutrophils found in CF lavage, sputum, and lung tissue $(39,40)$. Although previous reports have clearly demonstrated an inhibitory effect of CF sera on PM phagocytosis, neutrophil phagocytosis of PA has not been found to be abnormal $(41,42)$. Neutrophil function, as measured by reduction of tetrazolium dye and chemiluminescence, is not impaired in CF patients $(43,44)$. Other investigators have implicated PA related exoproducts for the suboptimal PA clearance by this massive influx of neutrophils. We suggest, based on our findings, that in the select subgroup of CF patients with IgG2 IC, neutrophil phagocytosis of PA may be further inhibited by these IC.

In summary, IgG2 exerted its phagocytosis inhibitory effect both by direct inhibition and by the formation of IC. The contributions of each, monomeric and complexed IgG2, cannot be ascertained with certainty. These observations further suggest that: (a) IgG2 elevation in CF sera may contribute to the establishment of PA colonization in the CF airway through inhibition of PA phagocytosis; $(b) \mathrm{IgG} 2$ is the predominant IgG subclass in CF IC; $(c)$ a portion of the measured IgG2 elevation in the serum from CF patients with circulating IC may be attributable to concurrent measurement of $\mathrm{IgG} 2$ in the IC; and $(d)$ these predominantly IgG2 IC, when present, inhibit not only PM but also neutrophil phagocytosis of PA, suggesting a dual cellular impairment in the clearance of PA from the CF airway. 


\section{Acknowledgments}

The authors wish to acknowledge the contribution of Dr. David Huston (Methodist Medical Center, Baylor University, Houston, TX) who generously performed the measurement of immune complexes and Dr. Steven Rennard (University of Nebraska) who provided the technical assistance for the IgG ELISA. Dr. Hal B. Richerson (University of Iowa) gratiously agreed to review the manuscript and provided critical comment. The expert secretarial assistance of Theresa Mayhew, Sandra Driscoll, and Kathy Stockton is appreciated.

This research was supported by an independent research grant from the Cystic Fibrosis Foundation and the National Institutes of Health (HL-35870).

\section{References}

1. Berdischewsky, M., M. Pollack, L. S. Young, D. Chia, A. B. Osher, and E. V. Barnett. 1980. Circulating immune complexes in cystic fibrosis. Pediatr. Res. 14:830-833.

2. Moss, R. B., Y.-P. Hsu, and N. J. Lewiston. 1981. ${ }^{125}$ I-Clq-binding and specific antibodies as indicators of pulmonary disease activity in cystic fibrosis. J. Pediatr. 99:215-222.

3. Hodson, M. E., I. Beldon, and J. C. Batten. 1985. Circulating immune complexes in patients with cystic fibrosis in relation to clinical features. Clin. Allergy. 15:363-370.

4. Schoitz, P. O., H. Nielson, N. Hoiby, G. Glilemann, and S.-E. Svehag. 1978. Immune complexes with sputum of patients with cystic fibrosis suffering from chronic Pseudomonas aeruginosa lung infection. Acta Pathol. Microbiol. Scand. Sect. C Immunol. 86:37-40.

5. Macfarlane, H., A. Holzel, P. Brenchley, J. D. Allan, J. C. Wellrock, B. E. Singer, and B. Worsley. 1975. Immune complexes in cystic fibrosis. Br. Med. J. 1:423-428.

6. Schotz, P. O., N. Hoiby, and F. Juhl. 1977. Immune complexes in cystic fibrosis. Acta Pathol. Microbiol. Scand. Sect. C Immunol. 85:57-64.

7. Moss, R. B., Y.-P. Hsu, N. J. Lewiston, J. G. Curd, H. Milgram, S. Hart, B. Dyer, and J. W. Larrick. 1986. Association of systemic immune complexes, complement activation and antibodies to Pseudomonas aeruginosa lipopolysaccharide and exotoxin A with mortality in cystic fibrosis. Am. Rev. Respir. Dis. 133:648-652.

8. Fick, R. B., G. P. Naegel, R. A. Matthay, and H. Y. Reynolds. 1981. Cystic fibrosis opsonins: inhibitory nature in an in vitro phagocytic assay. J. Clin. Invest. 68:899-914.

9. Fick, R. B., J. Olchowsky, S. U. Squier, W. W. Merrill, and H. Y. Reynolds. 1986. Immunoglobulin G subclasses in cystic fibrosis: IgG response to Pseudomonas aeruginosa lipopolysaccharide. Am. Rev. Respir. Dis. 133:418-422.

10. Nydegger, U. E., P. H. Lambert, H. Gerber, and P. A. Miescher. 1979. Circulating immune complexes in the serum in systemic lupus erythematosis and in carriers of hepatitis B antigen: quantitation by binding to radiolabeled Clq. J. Clin. Invest. 54:297-309.

11. Creighton, W. D., P. H. Lambert, and P. A. Miescher. 1973. Detection of antibodies and soluble antigen-antibody complexes by precipitation with polyethylene glycol. J. Immunol. 111:1219-1227.

12. Rennard, S. T., R. Berg, G. R. Martin, J. M. Fordart, and P. G. Robey. 1980. Enzyme-linked immunoassay (ELISA) for connective tissue components. Anal. Biochem. 104:205-214.

13. Neter, E., O. Westphal, O. Luderitz, A. Gorzynski, and E. Eicherberger. 1956. Passive hemagglutination to quantitate antibody responses. J. Immunol. 76:377-382.

14. Fick, R. B., G. P. Naegel, S. U. Squier, R. E. Wood, J. B. L. Gee, and H. Y. Reynolds. 1984. Proteins of the cystic fibrosis respiratory tract: fragmented IgG opsonic antibody causing defective opsonophagocytosis. J. Clin. Invest. 74:236-248.

15. Harris, J. O., E. W. Swenson, and J. E. Johnson. 1970. Human alveolar macrophages: comparison of phagocytic ability, glucose utili- zation, and ultrastructure in smokers and nonsmokers. J. Clin. Invest. 49:2086-2096.

16. Metcalf, J. A., J. I. Gallin, W. M. Nauseef, and R. K. Root. 1986. Laboratory Manual of Neutrophil Function. Raven Press, New York.

17. Thomassen, M. J., B. Boxerbaum, C. A. Demko, P. J. Kuchenbrod, D. G. Dearborn, and R. E. Wood. 1979. Inhibitory effect of cystic fibrosis serum on Pseudomonas phagocytosis by rabbit and human alveolar macrophages. Pediatr. Res. 13:1085-1088.

18. Shryock, T. R., J. S. Molle, J. D. Klinger, and M. J. Thomassen. 1986. Association with phagocytic inhibition of anti-Pseudomonas aeruginosa immunoglobulin $\mathrm{G}$ antibody subclass levels in serum from patients with cystic fibrosis. J. Clin. Microbiol. 23:513-516.

19. Fomsgaard, A., N. Hoiby, G. H. Shand, R. S. Conrad, and C. Galanos. 1988. Longitudinal study of antibody response to lipopolysaccharides during chronic Pseudomonas aeruginosa lung infection in cystic fibrosis. Infect. Immun. 56:2270-2278.

20. Hornick, D. B., and R. B. Fick. 1986. Postulated role of IgG2 antibodies in delayed clearance by macrophages and persistence of immune complexes. Am. Rev. Respir. Dis. 133:A8.

21. Djurup, R. 1985. The subclass nature and clinical significance of IgG antibody response in patients undergoing allergy and specific immunotherapy. Allergy. 40:469-486.

22. Ishizaka, T., K. Ishizaka, S. Salmon, and H. Fudenberg. 1967. Biologic activities of aggregated gammaglobulin. VIII. Aggregated immunoglobulins of different classes. J. Immunol. 99:82-91.

23. Pier, G. B. 1985. Pulmonary disease associated with pseudomonas aeruginosa and cystic fibrosis: current status of the host-bacterium interaction. J. Infect. Dis. 151:575-580.

24. Speert, D. P. 1985. Host defenses in patients with cystic fibrosis: modulation by Pseudomonas aeruginosa. Surv. Synth. Pathol. Res. 4:14-33.

25. Engels, W., J. Endert, M. A. F. Kamps, and C. P. A. Van Boven. 1985. Role of lipopolysaccharide in opsonization and phagocytosis of Pseudomonas aeruginosa. Infect. Immun. 49:182-189.

26. Shur, P. H. 1972. Human gamma-G subclasses. Prog. Clin. Immunol. 1:71-104.

27. Kurlander, R. J., and J. Batker. 1982. The binding of human immunoglobin G1 monomer and small, covalently cross-linked polymers of immunoglobulin G1 to human peripheral blood monocytes and polymorphonuclear leukocytes. J. Clin. Invest. 69:1-8.

28. Naegel, G. P., K. R. Young, and H. Y. Reynolds. 1984. Receptors for human IgG subclasses on human alveolar acrophages. Am. Rev. Respir. Dis. 129:413-418.

29. Hornick, D. B., and R. B. Fick. 1987. The IgG subclass composition of cystic fibrosis immune complexes relative to the pathogenesis of cystic fibrosis lung disease. Clin. Res. 35:866. (Abstr.)

30. Karas, S. P., W. F. Rosse, and R. J. Kurlander. 1982. Characterization of the IgGFc receptor on human platelets. Blood. 60:12771282.

31. Kulczycki, A., Jr. 1984. Human neutrophils and eosinophils have structurally distinct FCC Receptors. J. Immunol. 133:849-854.

32. Moss, R. B. 1987. Hypergammaglobulinemia in cystic fibrosis: role of Pseudomonas endobronchial infection. Chest. 91:522-526.

33. Dasgupta, M. K., P. Zuberbuhler, A. Abbi, F. L. Harley, N. E. Brown, K. Lam, J. B. Dossetor, and J. W. Costerton. 1987. Combined evaluation of circulating immune complexes and antibodies to Pseudomonas aeruginosa as an immunologic profile in the relation to pulmonary function and cystic fibrosis. J. Clin. Immunol. 7:51-58.

34. Wisnieski, J. J., E. W. Todd, R. K. Fuller, P. K. Jones, D. G. Dearborn, T. F. Boat, and G. B. Nalf. 1985. Immune complexes and complement abnormalities in patients with cystic fibrosis: increased mortality associated with circulating immune complexes and decreased function of the alternate complement pathway. Am. Rev. Respir. Dis. 132:770-776.

35. Hardin, J. A., L. C. Walker, A. C. Steere, T. C. Trumble, K. S. K. Tung, R. C. Williams, S. Ruddy, and S. E. Malawista. 1979. 
Circulating immune complexes in lyme arthritis: detection by the ${ }^{125} \mathrm{I}-$ Clq binding, Clq solid phase, and Raji cell assays. J. Clin. Invest. 63:468-477.

36. Zubler, R. H., and P. H. Lambert. 1978. Detection of immune complexes in human diseases. Prog. Allergy. 24:1-48.

37. Lambert, P. H., F. J. Dixon, R. H. Zubler, V. Agnello, C. Caruliaso, P. Casali, J. Clarke, J. S. Cowdery, F. C. McDuffie, F. C. Hay, et al. 1978. A WHO collaborative study for the evaluation of eighteen methods for detecting immune complexes in serum. J. Clin. Lab. Immunol. 1:1-15.

38. Moss, R. B., and N. J. Lewiston. 1980. Immune complexes and humoral response to Pseudomonas aeruginosa in cystic fibrosis. Am. Rev. Respir. Dis. 121:23-29.

39. Barten, A. D., K. Ryder, and R. V. Lourenco. 1976. Inflammatory reaction and airway damage in cystic fibrosis. J. Lab. Clin. Med. $88: 423$.

40. Hornick, D. B., and R. B. Fick. 1987. Immunochemical studies of cystic fibrosis lung fluid, an important clinical tool to assess airway inflammation. Am. Rev. Respir. Dis. 135:A465.
41. Boxerbaum, B., M. Kagumba, and L. W. Matthews. 1973. Selective inhibition of phagocytic activity of rabbit alveolar macrophages by cystic fibrosis serum. Am. Rev. Respir. Dis. 108:777-783.

42. di Sant 'Agnese, P. A., and P. B. Davis. 1976. Research in cystic fibrosis. (Third of three parts). N. Engl. J. Med. 295:597-603.

43. Hill, H. R., W. J. Warwick, and J. Dettloff. 1974. Neutrophil granulocyte function in patients with pulmonary infection. J. Pediatr. 84:55-59.

44. Graft, D. F., E. Mischler, and P. M. Farrell. 1982. Granulocyte chemiluminescence in adolescent patients with cystic fibrosis. Am. Rev. Respir. Dis. 125:540-553.

45. Scharmann, W., F. Jacob, and G. Porstendorfer. 1976. Cytotoxic action of leukocidin from $P$. aeruginosa on human polymorphonuclear leukocytes. J. Gen. Microbiol. 93:303-309.

46. Vishwanath, S., R. Ramphal, C. M. Guay, D. Des Jardens, and G. B. Pier. 1988. Respiratory-mucin inhibition of the opsonophagocytic killing of Pseudomonas aeruginosa. Infect. Immun. 56:22182222. 